\title{
Correction to: Evaluation of forty-five cultivars as affected by bulb initiation, bulb and scale characteristics, and bulb minerals and organic compounds of intermediate-day yellow onion (Allium cepa L.) in South Korea
}

\author{
Jongtae Lee ${ }^{1} \mathbb{D}$ - Juyeon Kim ${ }^{1} \cdot$ Jin-Hyeuk Kwon ${ }^{1} \cdot$ Young-Ho Chang ${ }^{1} \cdot$ Young-Seok Kwon $^{2} \cdot$ Tae-Ja Kim $^{1}$. \\ Mi-Jung Park ${ }^{1} \cdot$ Mi-Ae Kim $^{1} \cdot$ Hyang-Mi Lee $^{1}$
}

Published online: 19 November 2020

(c) Korean Society for Horticultural Science 2020

\section{Correction to: \\ Horticulture, Environment, and Biotechnology \\ https://doi.org/10.1007/s13580-020-00282-2}

The original version of this article unfortunately contained two mistakes. A percent sign was missing in the abstract, and in Sect. 3.2, a sentence incorrectly read as "Many researchers showed differences in minerals contents as affected by different cultivars, but it was evident what made the differences.", while it should read as "Many researchers showed differences in minerals contents as affected by different cultivars, but it was not evident what made the differences."

The original article has been corrected.

Publisher's Note Springer Nature remains neutral with regard to jurisdictional claims in published maps and institutional affiliations.

The original article can be found online at https://doi.org/10.1007/ s13580-020-00282-2.

Jongtae Lee

organicjt@korea.kr; organicjt@hotmail.com

1 Onion Research Institute, Gyeongsangnam-do Agricultural

Research and Extension Services, Changnyeong 50319,

Republic of Korea

2 Department of Vegetable, National Institute of Horticultural and Herbal Science, Wanju 55365, Republic of Korea 